\title{
Social Movements
}

The Structure of Collective Mobilization

PAUL ALMEIDA

甲

University of California Press 
University of California Press, one of the most distinguished university presses in the United States, enriches lives around the world by advancing scholarship in the humanities, social sciences, and natural sciences. Its activities are supported by the UC Press Foundation and by philanthropic contributions from individuals and institutions. For more information, visit www.ucpress.edu.

University of California Press

Oakland, California

(C) 2019 by The Regents of the University of California

Library of Congress Cataloging-in-Publication Data

Names: Almeida, Paul, author.

Title: Social movements : the structure of collective mobilization /

Paul Almeida.

Description: Oakland, California : University of California Press, [2019] |

Includes bibliographical references and index. |

Identifiers: LCCN 2018033480 (print) | LCCN 2018035307 (ebook) |

ISBN 9780520964846 | ISBN 9780520290914 (pbk. : alk. paper)

Subjects: LCSH: Social movements-Textbooks.

Classification: LCC HM881 (ebook) | LCC HM881 .A397 2019 (print) |

DDC $303.48 / 4$-dc23

LC record available at https://lccn.loc.gov/2018033480

Manufactured in the United States of America

$\begin{array}{llllllll}26 & 25 & 24 & 23 & 22 & 21 & 20 & 19\end{array}$

$\begin{array}{llllllllll}10 & 9 & 8 & 7 & 6 & 5 & 4 & 3 & 2 & 1\end{array}$ 
Social Movements 
